\title{
Plasma urea concentrations in the general population: comparison with 'hospital normal values'
}

\author{
W. E. WATERS \\ M.B., B.S., D.I.H. \\ Members of Scientific Staff, \\ M.B., B.Ch. \\ Medical Research Council, Epidemiological Research Unit (South Wales) \\ J. W. KEYSER \\ M.Sc., Ph.D., F.R.I.C., M.C.Path. \\ Reader in Chemical Pathology, University of Wales, \\ at The Welsh Nationa School of Medicine; \\ Honorary Consultant in Biochemistry, United Cardiff Hospitals
}

W. J. W. GreENE

THE DISTRIBUTION of blood biochemical variables can be investigated in several ways. Healthy volunteers have been used to provide ideal or 'normal' values. Data obtained from hospital laboratories have been analysed statistically to provide 'normal' ranges which are assumed to be more representative of the community (Pryce, 1960, 1964). Finally, a representative sample of the community, preferably taken over a wide area, can be used to measure the distribution of such variables in the general population. During the period November 1965 to April 1966 the Epidemiological Research Unit (South Wales) conducted a pilot survey in a stratified random sample of electors in Wales.* Details of the method of the survey are reported elsewhere (Campbell et al., 1968). The opportunity was taken of estimating the plasma urea in the blood remaining after the haematological investigations, and in this paper these data are compared with results obtained with hospital inpatients. Men with the highest plasma urea concentrations in the community study were followed up for evidence of renal disease. In addition we have investigated diurnal variation and the effect of a protein meal on the plasma urea concentration.

\section{Methods}

Community survey

The thirty-six parliamentary constituencies in Wales were arranged in groups of six according to the number of electors per acre. One constituency was randomly selected from each group and a sample of 100 electors was drawn from

\footnotetext{
*For the purpose of this survey, Wales includes Monmouthshire.
}

the electoral rolls of each of these six constituencies, using tables of random numbers. The population sample so obtained consisted, therefore, of 600 men and women over the age of 21 . Samples of venous blood were taken by general practitioners, public health medical officers or teams from the Epidemiological Research Unit, placed in sequestrene bottles and driven or posted to the laboratory, where the plasma urea was estimated.

At a follow-up the twelve men with the highest urea concentrations were revisited in their homes, as were eleven of twelve controls who were matched for sex, age and constituency and who had a plasma urea concentration of less than 40 $\mathrm{mg} / 100 \mathrm{ml}$. Enquiry was made about urinary symptoms and any past history of renal disease, the blood pressure was measured, a specimen of urine collected for examination for the presence of cells, casts, protein and bacteria, and a sample of blood taken for a second urea determination. The doctor making these visits did not know the initial urea result and hence which men were in the 'high-urea' and which in the control groups.

\section{Hospital patients}

Five hundred results for plasma urea concentration in hospital in-patients at the Cardiff Royal Infirmary during the months of January, February and March 1966 were taken from laboratory records, this period being chosen as it approximated to the middle period of the community survey. The first 167 results for January were noted, after excluding: (a) repeat determinations on the same patient, (b) out-patients, (c) persons in the community survey, and (d) a few emergency determinations (these were, in any case, mostly repeat determinations). In a similar way 167 
results were collected for February and 166 for March, making a total of 500. Thirteen results were excluded because details of age and sex could not be traced.

\section{Analytical}

In all cases the blood was centrifuged and the plasma urea determined by the diacetyl monoxime method, using the AutoAnalyzer (Technicon method N-1a). In our experience the use of whole blood occasionally causes blocking of tubes in the apparatus, and blood urea determinations at the Cardiff Royal Infirmary are routinely done on plasma or serum. Using the AutoAnalyzer we have found that over the normal range the plasma urea concentration is, on the average, $3 \mathrm{mg} / 100$ $\mathrm{ml}$ higher than that of whole blood. The plasma values we report may therefore readily be converted to values for whole blood. Standards and controls were run with every set of determinations.

Diurnal variation and the effect of a high-protein meal

Duplicate venous blood samples for determination of urea concentration were taken from four men and four women volunteers every $3 \mathrm{hr}$ from 08.00 hours until 23.00 hours on two successive days. The diet of these volunteers was not controlled in any way.

In further experiments the effect on the plasma urea concentration of a single high-protein meal (containing 80-100 g protein) taken on the 2nd day of a period of an otherwise low-protein diet (less than $30 \mathrm{~g}$ protein per day) was investigated by taking duplicate venous blood samples over 3 days from two male volunteers.

For both the diurnal variation and high-proteinmeal studies the technician determining the urea concentrations was unaware of the times the samples were taken and the identity of the donors.

\section{Results}

Community survey

From the original sample of 600 we excluded eighty-two subjects who had died or left the area since the electoral roll was compiled or who were over the age of 75 years. From the remaining 253 men and 265 women plasma urea was determined on $217(85.8$ per cent) and $215(81 \cdot 1$ per cent), respectively. There were nineteen men and thirty-seven women who refused to co-operate or who could not be contacted and in a further thirty cases there was insufficient blood.

The mean plasma urea concentrations and standard deviations for men and women are given by constituency in Table 1 . The distribution of urea is given in Table 2 and in Fig. 1. The overall
TABLE 1

Mean plasma urea concentration $(\mathrm{mg} / 100 \mathrm{ml})$ and standard deviation by constituency for men and women in the community study

\begin{tabular}{|c|c|c|c|c|c|c|}
\hline \multirow[b]{2}{*}{ Constituency } & \multicolumn{3}{|c|}{ Men } & \multicolumn{3}{|c|}{ Women } \\
\hline & No. & Mean & $\overline{\text { SD }}$ & No. & Mean & $\overline{\text { SD }}$ \\
\hline \multicolumn{7}{|l|}{ Brecon and } \\
\hline Radnor & 37 & 33.4 & $6 \cdot 7$ & 35 & $29 \cdot 1$ & $5 \cdot 4$ \\
\hline Monmouth & 31 & $32 \cdot 8$ & $7 \cdot 4$ & 34 & $29 \cdot 3$ & $6 \cdot 8$ \\
\hline East Flint & 41 & $31 \cdot 5$ & 6.9 & 38 & $28 \cdot 7$ & $7 \cdot 6$ \\
\hline Aberdare & 45 & $29 \cdot 6$ & $5 \cdot 7$ & 26 & $26 \cdot 6$ & $6 \cdot 4$ \\
\hline Abertillery & 32 & $32 \cdot 4$ & $5 \cdot 8$ & 37 & $27 \cdot 2$ & 5.9 \\
\hline Newport & 31 & $31 \cdot 7$ & $6 \cdot 2$ & 45 & $30 \cdot 4$ & 8.9 \\
\hline Total & 217 & $31 \cdot 8$ & $6 \cdot 5$ & 215 & $28 \cdot 7$ & $7 \cdot 1$ \\
\hline
\end{tabular}

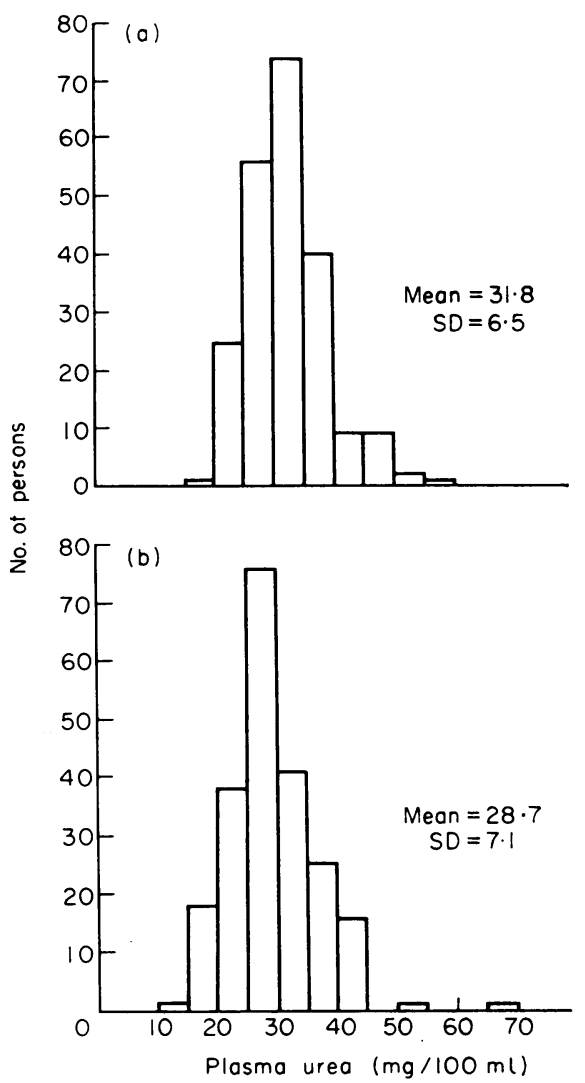

FIG. 1. The distribution of plasma urea concentration in (a) 217 men and (b) 215 women in the community study.

TABLE 2

Distribution of plasma urea concentration $(\mathrm{mg} / 100 \mathrm{ml})$ in 217 men and 215 women drawn from the electoral rolls of Wales

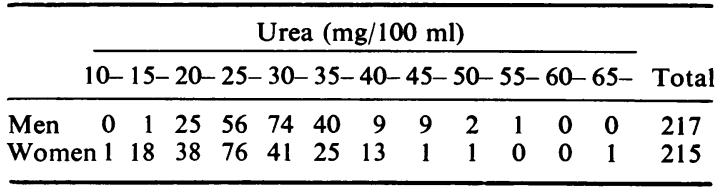


mean for men is $31.8 \mathrm{mg} / 100 \mathrm{ml}$ with a standard deviation of 6.5 ; the mean for women is $28.7 \mathrm{mg}$ / $100 \mathrm{ml}$ with a standard deviation of $7 \cdot 1$. The difference between these means is highly significant $(t=4.7 ; P<0.001)$. In both sexes the urea concentration increased with age (Figs. 2 and 3). The association between plasma urea concentration and age is given by the regression equations:

$$
\begin{aligned}
& y_{\text {men }}=27.9+0.089 x \\
& y_{\text {women }}=21.4+0.160 x
\end{aligned}
$$

where $y$ is the plasma urea $(\mathrm{mg} / 100 \mathrm{ml})$ and $x$ the age (in years). Both these regression coefficients are significant (men: $P<0.01$; women: $P<0.001$ ). Covariance analysis of plasma urea $(y)$ and age $(x)$ shows no significant difference in the regression coefficients of men and women $(F=2.51)$ but there is a significant difference in their positions $(F=26.91 ; P<0.001)$. Therefore, the difference between the mean urea concentrations in men and women is not likely to be entirely due to any age differences between men and women in the sample.

A summary of the results of the follow-up of twelve men with the highest urea concentrations $(45 \mathrm{mg} / 100 \mathrm{ml}$ or above) is given in Table 3. In the high-urea group, the repeat urea values (the means of duplicate determinations) were again above $45 \mathrm{mg} / 100 \mathrm{ml}$ in six cases, between 40 and $45 \mathrm{mg}$ in three cases and below $40 \mathrm{mg}$ in three cases. The high-urea group had a higher mean blood pressure and for the diastolic level this difference was statistically significant $(t=2 \cdot 78$, $0.02>P>0.01)$. In five no abnormality was found,

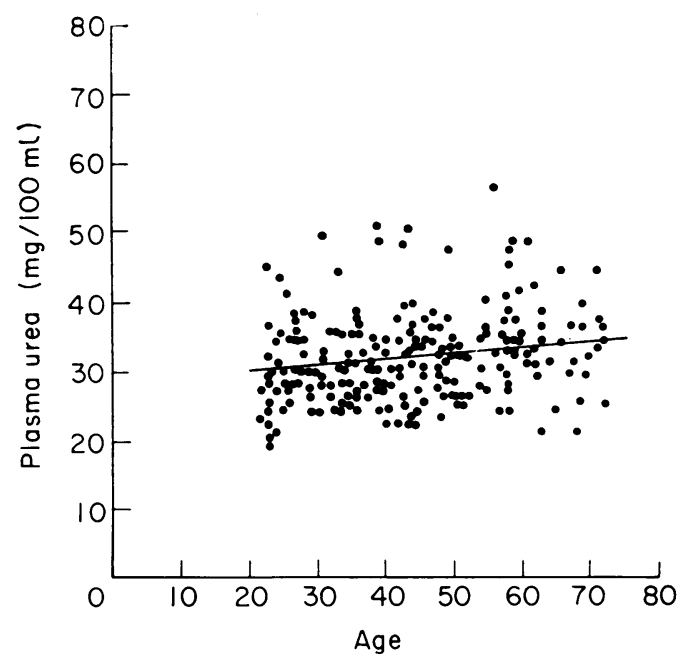

Fig. 2. The relation of age (in years) and plasma urea concentration $(\mathrm{mg} / 100 \mathrm{ml})$ in $217 \mathrm{men}$ in the community study.

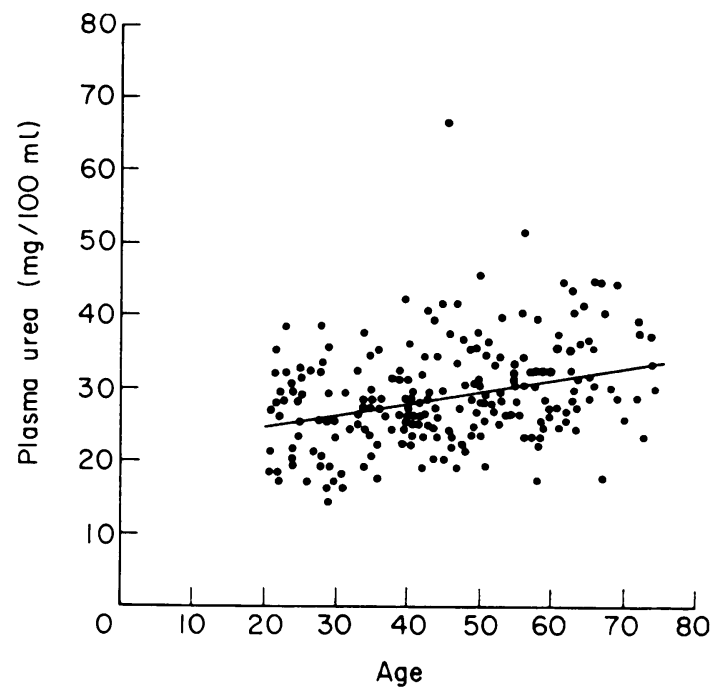

FIG. 3. The relation of age (in years) and plasma urea concentration $(\mathrm{mg} / 100 \mathrm{ml})$ in 215 women in the community study.

except for the urea concentration, and on followup three of these were still above $42 \mathrm{mg} / 100 \mathrm{ml}$. The man with the highest plasma urea in whom no other abnormality was detected had a concentration of $50 \mathrm{mg} / 100 \mathrm{ml}$. None of the controls had a urea concentration above $40 \mathrm{mg} / 100 \mathrm{ml}$ on follow-up.

\section{Hospital patients}

The overall mean plasma urea concentration in 252 males was $51.3 \mathrm{mg} / 100 \mathrm{ml}$ and in 248 females $51.4 \mathrm{mg} / 100 \mathrm{ml}$. The methods for obtaining 'normal' values from routine hospital data have been given by Pryce $(1960,1964)$ and these methods were applied to our hospital data. In

TABLE 3

Follow-up of high-urea and control groups (men)

\begin{tabular}{lcc}
\hline & $\begin{array}{c}\text { High-urea } \\
\text { group } \\
\text { No. in group }\end{array}$ & $\begin{array}{c}\text { Controls } \\
11\end{array}$ \\
\hline Mean plasma urea $(\mathrm{mg} / 100 \mathrm{ml})$ & & \\
$\quad$ Initial $( \pm \mathrm{SD})$ & $48 \cdot 4( \pm 2 \cdot 9)$ & $29 \cdot 7( \pm 5 \cdot 6)$ \\
$\quad$ Follow-up $( \pm \mathrm{SD})$ & $44 \cdot 4( \pm 8 \cdot 7)$ & $31 \cdot 5( \pm 6 \cdot 1)$ \\
Blood pressure & $141( \pm 24)$ & $130( \pm 15)$ \\
$\quad$ Mean systolic $( \pm \mathrm{SD})$ & $89( \pm 15)$ & $75( \pm 8)$ \\
$\quad$ Mean diastolic $( \pm \mathrm{SD})$ & 4 & 1 \\
History of urinary symptoms & 1 & 0 \\
Protein present in urine & 1 & 0 \\
$\quad$ Definite & 1 & 3 \\
$\quad$ Faint & 1 & 1 \\
$\quad$ Exceedingly faint & 0 & 1 \\
Abnormal urinary deposit & 5 & 6 \\
Bacteria in urine (single culture only) & & \\
No abnormality detected & &
\end{tabular}


order to make the results comparable with those obtained in the community survey we have excluded ninety-five persons under 21 or over 75 years of age. As the distribution is obviously skewed (Fig. 4) we used the mode as the best

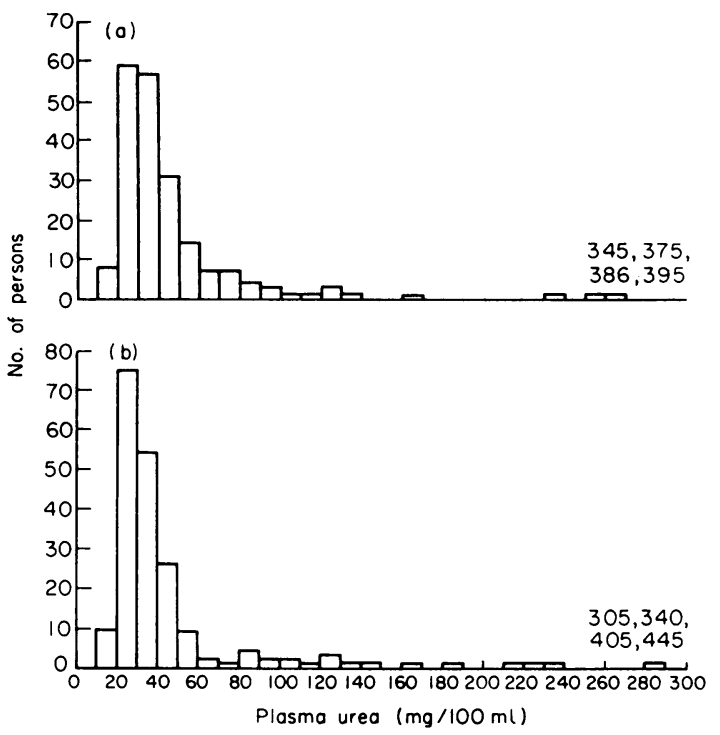

FIG. 4. The distribution of plasma urea concentration in (a) 204 men and (b) 201 women hospital patients aged 21-74 years.

estimate of the 'normal' mean. Using the formula : mode $=$ mean -3 (mean - median) we obtained a mode of 2.38 for men and a negative value for women. Obviously the urea distribution is too skewed for this formula to be valid, so the mode was selected by taking fine groupings (1-mg intervals) in the region of the mode and estimating five-fold moving averages so that a clear maximum point was obtained. This mode was taken as the best estimate of the mean for normal urea concentrations and the standard deviation was calculated, using only the values on the non-skewed side. From the 'normal' values thus obtained a correlation between urea concentration and age was found, so the data were re-calculated for the two age groups 21-49 years and 50-75 years, each sex being treated separately, to prevent the elimination of some of the higher values in older patients. The 'normals' obtained in this way for the two age ranges were combined. The data for these patients are shown in Table 4.

The mean urea concentration thus calculated for hospital 'normals' aged from 21 to 75 years is $31.0 \mathrm{mg} / 100 \mathrm{ml}$ for men and $30.6 \mathrm{mg} / 100 \mathrm{ml}$ for women. There is no significant difference between these means. The mean age for these hospital 'normals' is 53 years for each sex. An
TABLE 4

Plasma urea concentrations $(\mathrm{mg} / 100 \mathrm{ml})$ of hospital in-patients

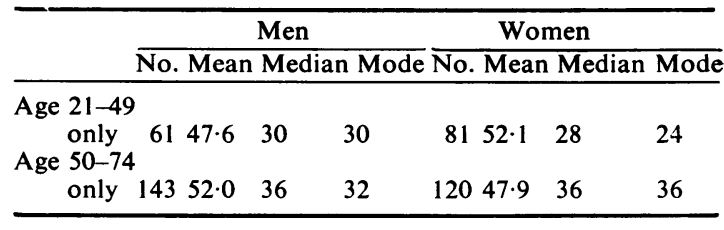

analysis of covariance of urea and age for hospital 'normals' shows that there is a significant difference in the slopes of the regression coefficients in men and women. The increase in urea concentration with age is significant in women but not in men (Table 5).

TABLE 5

Mean plasma urea concentration $(\mathrm{mg} / 100 \mathrm{ml})$ with standard deviations and regression coefficients of urea on age (years) for 'hospital normals' and the random sample

\begin{tabular}{lccccc}
\hline & No. & Mean SD & $\begin{array}{c}\text { Regression } \\
\text { coefficient }\end{array}$ \\
\hline $\begin{array}{c}\text { 'Hospital normals' - } \\
\text { men 21-75 years }\end{array}$ & 149 & 31.0 & 7.6 & 0.053 & $P>0.2$ \\
$\begin{array}{c}\text { Community survey - } \\
\text { men 21-75 years }\end{array}$ & 217 & 31.8 & 6.5 & 0.089 & $P<0.01$ \\
'Hospital normals' - \\
$\begin{array}{c}\text { women 21-75 years } \\
\text { Community survey - }\end{array}$ & 155 & 30.6 & 9.1 & $0.306 P<0.001$ \\
$\begin{array}{c}\text { women 21-75 years } \\
\text { women }\end{array}$ & 215 & 28.7 & 7.1 & $0.160 P<0.001$ \\
\hline
\end{tabular}

Diurnal variation and the effect of a high protein meal

The plasma urea concentrations of each of the eight volunteers showed considerable individual fluctuation, with daily ranges of between 3 and 9 $\mathrm{mg} / 100 \mathrm{ml}$ (average daily range $5.6 \mathrm{mg} / 100 \mathrm{ml}$ ) but there was little evidence of a consistent pattern. The correlation between the duplicate estimations from specimens taken at the same time was extremely high $(r=0.95)$. The means show no marked trend during the day (Table 6), although the lowest values in both sexes occurred at $\mathbf{1 4 . 0 0}$ hours.

TABLE 6

Mean plasma urea concentration $(\mathrm{mg} / 100 \mathrm{ml})$ and standard error in four men and four women volunteers estimated in duplicate on two successive days

\begin{tabular}{lllllll}
\hline & \multicolumn{6}{c}{ Time (hours) } \\
\cline { 2 - 7 } & 08.00 & 11.00 & 14.00 & 17.00 & 20.00 & 23.00 \\
\hline Men & & & & & & \\
Mean & 29.4 & 28.5 & 28.0 & 30.0 & 29.5 & 29.4 \\
SE & 1.78 & 1.51 & 1.37 & 2.14 & 2.20 & 1.61 \\
Women & & & & & & \\
Mean & 29.6 & 29.6 & 28.2 & 30.8 & 31.7 & 29.6 \\
SE & 1.62 & 1.82 & 1.55 & 1.72 & 1.85 & 1.93 \\
\hline
\end{tabular}


The effect of a high-protein meal on the plasma urea concentration in two experiments is shown in Fig. 5. There was a maximum rise in plasma urea of $10-14 \mathrm{mg} / 100 \mathrm{ml} \mathrm{3-7} \mathrm{hr}$ after the meal.

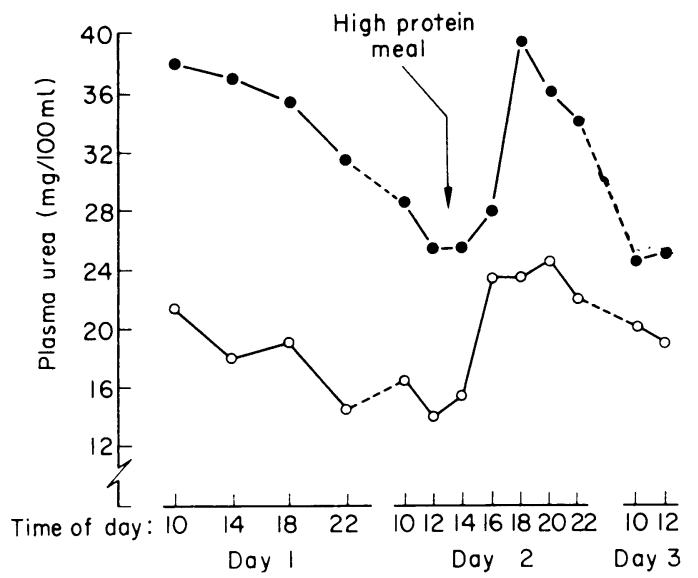

FIG. 5. The effect of a high-protein meal (80-100 $\mathrm{g}$ of protein) on the plasma urea concentration in two subjects. First subject; $\mathrm{O}$, second subject.

\section{Discussion}

The distributions of plasma urea concentrations from the community survey and from hospital inpatients show considerable differences. In particular the hospital 'normal' data do not show a significant difference between the means for men and women, nor do they give a significant regression coefficient with age in men. The hospital results were selected to coincide with the middle of the community survey as the possibility of a seasonal variation in blood urea concentration has been suggested (Pucher et al., 1934).

The procedures used to obtain 'normal' values from hospital data are based on the assumptions that: (1) patients are more representative of the parent population than are selected healthy subjects; (2) most laboratory data fall within the normal range; and (3) skewing of the distribution curve is due to the presence of abnormal values, and, if this is allowed for, a normal range can be calculated from data obtained with patients. We should not have thought that the selection of patients for urea estimation is particularly rigorous and we conclude that in certain respects we have failed to obtain similar results from our analysis of hospital data and the community survey. This finding is perhaps not unexpected as hospital in-patients and subjects in a community survey may experience considerable differences in respect of diet, physical activity and so on.

A sex difference in the blood urea concentrations of apparently healthy people was noted by
MacKay \& MacKay (1927), who found a mean of $33.0 \mathrm{mg} / 100 \mathrm{ml}(\mathrm{SD} 4.6)$ in men and of $24.4 \mathrm{mg}$ (SD 5.9) in women. Our corresponding mean values, corrected for the plasma-whole blood difference, are about 29 and $26 \mathrm{mg}$. A sex difference in plasma urea concentration in healthy young adults was also found by Björnesjö (1963), who found a mean, per $100 \mathrm{ml}$, of 30.4 (SD 6.4) in men and 23.8 (SD 5.8) in women; and from laboratory data Pryce (1960) has estimated a normal mean urea of 34.0 (SD 7.1) for males and $29 \cdot 0$ (SD 5.6) for females.

MacKay \& MacKay (1927) demonstrated a rise in blood urea concentration throughout the day in six medical students when put on a standard diet. During the present community survey there was a tendency for blood samples to be taken from women during the morning and afternoon and from men later in the day, after working hours. If there was a consistent diurnal variation, with higher urea values occurring later in the day, this could have led to a spurious sex difference between the means. However, it seems unlikely that the diurnal variation found in our investigation without altering diet habits (Table 6 ) is sufficient to account for the sex difference found in the community survey.

The difference in means between men and women may be due to differences in protein intake. Widdowson \& McCance (1936) found a higher protein intake in men, as compared with women, in the English middle class; and Addis et al. (1947) found that when the daily protein intake in young men was increased from 0.5 to $2.5 \mathrm{~g} / \mathrm{kg}$ body weight the mean plasma urea concentration increased from $19 \cdot 3$ to $45 \mathrm{mg} / 100 \mathrm{ml}$. Protein intake may also contribute to the fluctuations of urea during the day in the same individual. A single meal is often thought to have little effect on the urea level (e.g. MacKay \& MacKay, 1927). Annino \& Relman (1959) found no significant increase after a meal, but their standard breakfast contained only $15 \mathrm{~g}$ of protein and blood specimens were taken at only $45 \mathrm{~min}$ and $2 \mathrm{hr}$ after the meal. Our experiments with a high-protein meal, taken during an otherwise low-protein diet, show that it can produce a considerable rise in plasma urea concentration 3-5 $\mathrm{hr}$ later.

The distribution of plasma urea concentrations in the community survey (Fig. 1) is slightly skewed in the case of men. Wootton, King \& Maclean Smith (1951) found a log-normal distribution for whole blood urea but their distributions were not given separately for each sex. Slight skewing in distribution for men was found in a survey in East Africa (Shaper \& Kyobe, 1963) and is also evident in the scattergram for males, but not in 
that for females, published by Pryce (1964) and the data for normal men over 40 years of age given by Lewis \& Alving (1938).

The presence of skewing in the distribution of plasma urea concentrations in men, but less so in women, suggested the desirability of follow-up studies. It is not implied that the highest urea concentrations in our random population sample are necessarily to be regarded as abnormal. However, published normal ranges are, in general, based on single determinations, and follow-up studies of persons with values in the upper part of such ranges do not appear to have been made.

Twelve men, representing $5.5 \%$ of all urea results for men in the community study, were found to have a plasma urea concentration of 45 $\mathrm{mg} / 100 \mathrm{ml}$ or above. The mean age of this group was 48 years (compared with a mean of 44 years for all the men) and only five were over 50 years of age.

The definition of a 'normal range' in clinical chemistry involves practical difficulties (Keyser, 1965). A small number of values in healthy individuals may lie outside the generally accepted range of two standard deviations on either side of the mean. Accepting this formula, the community study data give a urea concentration range of $32 \pm 13$ (i.e. $19-45) \mathrm{mg} / 100 \mathrm{ml}$ for men. We could detect no abnormality in five out of twelve men with urea levels above this range. However, we did find evidence of some urinary abnormality in five out of eleven controls, or three if the mere presence of an exceedingly faint trace of protein is disregarded. (This trace was detected only by the boiling test and not by either the Albustix or the sulphosalicylic acid test.)

For certain estimations variation within an individual has been found to lie within relatively narrow limits compared with the normal range for the population as a whole (see Keyser, 1965). This, however, does not seem to apply to the plasma urea concentration. Its variability is stressed by Addis et al. (1947), and Pucher et al. (1934) found that, within the same subjects, the urea concentration was unusual in having a higher coefficient of variation in blood (average 20.4) than in urine (average 18.8). Our study of diurnal variation and the effects of a high-protein meal confirm that within the same individual the plasma urea concentration shows considerable variability.

\section{Summary}

The distribution of plasma urea concentrations in the general population was determined in $\mathbf{4 3 2}$ subjects drawn at random from the electoral rolls of six parliamentary constituencies in Wales. The mean for men was $31.8 \mathrm{mg} / 100 \mathrm{ml}$ (SD 6.5) and for women 28.7 (SD 7·1). The difference between these means is statistically significant and in both sexes the urea concentration was found to increase with age. Urea concentrations in hospital patients were analysed statistically in an effort to obtain 'normal values' but these showed some difference from those of the community survey. The diurnal variation in urea concentration was studied in eight volunteers and wide fluctuations within the same individual were found, depending at least in part on the protein intake. The results of a follow-up of the twelve men with the highest urea concentrations in the community survey are given.

\section{Acknowledgments}

We are grateful to the many doctors who helped obtain the blood samples; to Dr H. Campbell, who organized the community study; to Professor A. L. Cochrane and the Staff of the Epidemiological Research Unit: to Dr R. A. Holman for the examination of the urines; to Miss C. Barrett, Miss P. Evans, Miss L. Kennedy, Mr L. Carne and Mr C. Parfitt for the urea determinations: to Miss M. Abernethy for the statistical analyses; and to Mr R. Marshall and $\mathrm{Mr} \mathrm{F}$. Moore for the preparation of the illustrations.

\section{References}

Addis, T., Barrett, E., Poo, L.J. \& Yuen, D.W. (1947) The relation between the serum urea concentration and the protein consumption of normal individuals. J. clin. Invest. 26, 869.

Annino, J.S. \& Relman, A.S. (1959) The effect of eating on some of the clinically important chemical constituents of the blood. Amer. J. clin. Path. 31, 155.

BJöRNESJö, K.B. (1963) The distribution of alpha amino nitrogen, urea nitrogen, and non-protein nitrogen between erythrocytes and plasma in healthy males and females. Scand. J. clin. Lab. Invest. 15 (Suppl. 69), 25.

Campbell, H., Greene, W.J.W., Keyser, J.W., Waters, W.E., WedDell, J.M. \& Withey, J.L. (1968) A pilot survey of haemoglobin and plasma urea concentrations in a random sample of adults in Wales, 1965/66. Brit. J. prev. soc. Med. (In press)

KeYSER, J.W. (1965) The concept of the normal range in clinical chemistry. Postgrad. med. J. 41, 443.

LeWIS, W.H. \& Alving, A.S. (1938) Changes with age in renal function in adult men; clearance of urea; amount of urea nitrogen in blood: concentrating ability of kidneys. Amer. J. Physiol. 123, 500.

MACKAY, E.M. \& MACKAY, L.L. (1927) The concentration of urea in the blood of normal individuals. J. clin. Invest. 4, 295.

PryCE, J.D. (1960) Level of haemoglobin in whole blood and red blood-cells, and proposed convention for defining normality. Lancet, ii, 333.

PRYCE, J.D. (1964) Interpretation of laboratory results. Postgrad. Med. 36, A56.

Pucher, G.W., Griffith, F.R., Brownell, K.A., Klein, J.D. \& CARMER, M.E. (1934) Studies in human physiology; urine chemistry; comparison of 24-hour and short period basal excretion; correlations between urine constituents and menstrual and seasonal variations. J. Nutr. 7, 131 .

ShAPER, A.G. \& KYOBE, J. (1963) Blood urea levels in young and middle-aged African males. E. Afr. med. J. 40, 301 .

Widdowson, E.M. \& MCCANCE, R.A. (1936) A study of English diets by the individual method. II. Women. J. Hyg. (Lond.), 36, 293.

Wootton, I.D.P., King, E.J. \& Maclean SMith, J. (1951) The quantitative approach to hospital biochemistry. Normal values and use of biochemical determinations for diagnosis and prognosis. Brit. med. Bull. 7, 307. 